\title{
ŠKOLSKE KNJIŽNICE \\ U VIRTUALNOM SVIJETU
}

\section{SCHOOL LIBRARIES IN THE VIRTUAL WORLD}

\author{
Nataša Mesić Muharemi \\ Osnovna škola Darda \\ natasa.mesic-muharemi@skole.hr \\ Zorka Renić \\ Medicinska škola Bjelovar \\ zorka.renic@skole.hr \\ Josip Strija \\ Gimnazija Petra Preradovića Virovitica \\ josip.strija@skole.hr
}

UDK / UDC [027.8-021.131:004.738.5]:616.2-044.372

Stručni rad / Professional paper

Primljeno / Received: 14. 12. 2020.

Prihvaćeno / Accepted: 3. 3. 2021.

\section{Sažetak}

Cilj. Cilj je rada prikazati bazu poveznica virtualnih knjižnica koju su oblikovali školski knjižničari, ukazati na važnost školskih knjižnica u $e$-učenju i korištenju novih tehnologija u obrazovanju te ulogu školske knjižnice u tome procesu.

Pristup/metodologija. U radu je kratka analiza virtualnih knjižnica koje su dostupne na repozitoriju školskoga knjižničarstva UDK02 te je napravljena svojevrsna taksonomija sadržaja, odnosno popis zastupljenih tema i podtema, ali i digitalnih alata koje su koristili školski knjižničari.

Rezultati. Na repozitoriju hrvatskoga knjižničarstva UDK02 nalaze se poveznice za 243 virtualne knjižnice. Od toga su 183 knjižnice osnovnih škola, a 60 srednjih škola.

Praktična primjena. Objedinjavanjem svih virtualnih knjižnica na jednome mjestu omogućuje se knjižničarima, ali i svim ostalim korisnicima, dostupnost velikoga broja različitih informacija. Osim toga, ta stranica može biti početak jedne zajedničke stranice za sve knjižničare.

Vjesnik bibliotekara Hrvatske 64, 1(2021), 303-317

ISSN 0507-1925 
Ograničenja. Potrebno je stalno ažurirati virtualnu stranicu knjižnice i provjeravati poveznice jer neke poveznice više nisu dostupne, ali, isto tako, postavljati i vlastite materijale.

Društveni značaj. Pandemija uzrokovana bolesti COVID-19 imala je ogroman utjecaj na društvo u cjelini, a školski su knjižničari virtualnim knjižnicama nastojali smanjiti/ublažiti sve elemente negativnog utjecaja. Nastavili su biti potpora odgojno-obrazovnome procesu tako što su upućivali na građu za učenje i poučavanje dostupnu online.

Originalnost. U radu su predstavljena kvalitetna rješenja školskih knjižničara u pružanju usluga svojim korisnicima tijekom pandemije izazvane bolesti COVID-19 i zatvaranja knjižnica na nacionalnoj razini. Rad upućuje i na važnost vidljivosti školske knjižnice te na njezinu važnost kao podrške odgojno-obrazovnoga procesa. Osim toga, kratka analiza upućuje i na mogućnosti poboljšanja i daljnjega razvoja.

Ključne riječi: COVID-19; e-učenje; Hrvatska mreža školskih knjižničara - repozitorij; školski knjižničar; virtualna knjižnica

\section{Abstract}

Goal. The paper aims to present the database of links of virtual libraries designed by school librarians, in order to highlight the importance of the school libraries' role in e-learning and the use of new technologies in education.

Approach/methodology. The paper presents an analysis of virtual libraries available in the repository of the school librarianship UDK02, the Croatian network of school librarians. The classification, i.e. the taxonomy of repository content was created with the list of topics, subtopics, and digital tools used by school librarians.

Results. The Croatian Library Repository UDK02 contains links to 243 virtual libraries (183 primary and 60 secondary school libraries).

Practical implementation. By uniting all virtual libraries in one place, the librarians and all other users have access to a large number of different information. Besides, this website could be the starting page for one joint page for all librarians in the future.

Limitations. It is necessary to constantly update virtual pages of all libraries and check the links because some links are no longer available after some time, and also publish our own new materials.

Social significance. The pandemic caused by the COVID-19 disease has had a huge impact on society as a whole. The school librarians have aimed to reduce/mitigate all elements of the negative impact with the activities of virtual libraries. The school librarians have continued to support the educational process by referring to available learning and teaching online materials.

Originality. The paper presents some high-quality solutions of school librarians in providing services to their users during the pandemic caused by the COVID-19 disease 
and after the closure of libraries at the national level. Furthermore, the paper emphasizes the importance of the school library visibility and the library's importance as a reinforcement to the educational process. In addition, a brief analysis indicates the opportunities for improvement and further development.

Keywords: COVID-19; The Repository of the Croatian Network of School Librarians; e-learning; school librarian; virtual library

\section{Uvod}

Pandemija uzrokovana bolesti COVID-19 imala je ogroman utjecaj na društvo u cjelini, na naš osobni i profesionalni život. Uslijed problema, izazova i mogućnosti uzrokovanih pandemijom, školske knjižnice promijenile su i prilagodile svoju ulogu, oblik i načini rada. U središtu je nastava na daljinu, $e$-učenje i poučavanje, a veliki je dio aktivnosti školske knjižnice, odnosno knjižničara, usmjeren na oblikovanje virtualnih knjižnica. Hrvatska mreža školskih knjižničara, kao strukovna udruga čiji je jedan od ciljeva unaprjeđivanje rada školskih knjižnica, pokrenula je prikupljanje i objedinjavanje poveznica virtualnih knjižnica na svome repozitoriju. U radu je dostupna analiza korištenih programa, ali i sadržaja i tema virtualnih knjižnica.

\section{E-učenje i školske knjižnice}

Slijede definicije nekoliko ključnih elemenata $e$-učenja koje je usko povezano s razvojem virtualnih knjižnica. Brz napredak informacijsko-komunikacijske tehnologije uzrokovao je velike promjene u području odgoja i obrazovanja i razvijanje $e$-učenja. $E$-učenje može se iznimno široko definirati kao korištenje tehnologija za oblikovanje obrazovnoga procesa, a ugrubo se može podijeliti na učenje na daljinu i hibridno učenje. ${ }^{1}$ Pod e-učenjem podrazumijeva se uporaba elektroničkih medija, digitalnih sadržaja i informacijsko komunikacijske tehnologije u obrazovanju, a u svrhu poboljšanja ključnih kompetencija za cjeloživotno učenje. Prema Preporukama Europskog parlamenta za cjeloživotno učenje, navodi se osam ključnih kompetencija: komunikacija na materinskom jeziku, komunikacija na stranom jeziku, matematička kompetencija i temeljne kompetencije u prirodnim znanostima i tehnologiji, digitalna kompetencija, kompetencija učenja, društvene i građanske kompetencije, smisao za inicijativu i poduzetništvo i kulturološka senzibilizacija i

1 Banek Zorica, M. E-učenje temeljeno na objektima učenja. // Informacijska tehnologija u obrazovanju / Lasić-Lazić, Jadranka (ur.). Zagreb: Zavod za informacijske studije Odsjeka za informacijske i komunikacijske znanosti Filozofskog fakulteta Sveučilišta, 2014. Str. 33-59. 
izražavanje. Sve su kompetencije jednako važne te se međusobno isprepliću. Tako su, npr. kompetencije u informacijskim i komunikacijskim tehnologijama prijeko potreban temelj učenja, a kompetencija učenja podupire sve aktivnosti u učenju. ${ }^{2}$

Poboljšanje ključnih kompetencija usko je povezano s $e$-učenjem, pri čemu valja naglasiti da $e$-učenje i poučavanje ne znači tek jednostavan prijenos tradicionalnih programa u nove medije, već označava i novi obrazovni model s novom strukturom i svrhom učenja i poučavanja, kriterijima vrednovanja, teorijama učenja i ulogom nastavnika. E-učenje omogućuje učenicima odabir tempa učenja, vraćanje na dijelove koji im nisu jasni ili preskakanje onoga što već znaju otprije. Osim učenika, i nastavnici imaju koristi jer mogu pratiti aktivnosti učenika, ostvariti bržu i lakšu komunikaciju, imaju odmah dostupnu statistiku i postotak riješenosti nekoga zadatka. Ukratko, $e$-učenje olakšava rad svih sudionika u odgojno-obrazovnome procesu, a na pitanje koja je uloga školske knjižnice i knjižničara, može se izdvojiti nekoliko odgovora.

Školske knjižnice moraju kvalitetno odgovoriti na sve veće izazove koje im postavlja suvremeno, društveno i obrazovno okruženje koje se sve brže mijenja i velik dio svojih aktivnosti i usluga preseliti u online okruženje. Nadalje, valja sve intenzivnije raditi na aktivnome sudjelovanju u procesima učenja u okvirima školskoga kurikuluma. Zbirke školskih knjižnica također se mijenjaju i sve je značajniji fokus na pribavljanje izvora informacija u digitalnome obliku i oblikovanju virtualnih knjižnica.

Kako bi sve pratili i primjenjivali, školski knjižničari redovito moraju ažurirati svoja znanja, prije svega, u području informacijskih vještina i informacijske pismenosti. ${ }^{3}$

Premda je svijest o ulozi digitalnih zbirki u učenju i školskoj nastavi već duže vrijeme prisutna u istraživanjima, ideja o školskoj knjižnici kao virtualnoj zajednici učenja izričito je prisutna tek 15 -ak godina. Nekoliko je autora koji su definirali značenja sve od digitalne do virtualne zajednice učenja. Digitalna se zajednica učenja poima kao portal za osnovne i srednje škole i obuhvaća zbirku digitalnih izvora, materijale za učenje i poučavanje te tehnološka pomagala. Sljedeća su razina virtualne zajednice učenja koje podrazumijevaju trajni proces komunikacije i golemo skladište digitalnih materijala, od e-knjiga, online-baza podataka do sadržaja koje su kreirali učenici, a sve dostupno tijekom cijele godine. ${ }^{4}$

\footnotetext{
2 Preporuka Europskog parlamenta i savjeta; ključne kompetencije za cjeloživotno učenje - Europski referentni okvir. // Metodika 11, 20 (2010), str. 175. [citirano: 2020-10-08]. Dostupno na: https://hrcak.srce.hr/61536.

3 Herring, E. J. Internetske i informacijske vještine: priručnik za učitelje i školske knjižničare. Zagreb: Naklada Nediljko Dominović, 2008. Str. XIII.

4 Dukić, Z. Školske knjižnice u virtualnom prostoru: od mrežne stranice do virtualne zajednice učenja. // XXIV. Proljetna škola školskih knjižničara Republike Hrvatske. Smjernice za rad školskog knjižničara / Mićanović, Miroslav (ur.). Zagreb: Agencija za odgoj i obrazovanje, 2012.
} 
U Hrvatskoj nije pokrenut sustavni koncept virtualne zajednice učenja, već paralelno i pojedinačno virtualne zajednice učenja razvijaju udruge, škole, nakladnici, a školski knjižničari započeli su s oblikovanjem virtualnih knjižnica s ciljem podrške odgojno-obrazovnome procesu te za kulturnu i javnu djelatnost. U knjižničarskoj se literaturi koriste termini poput elektroničke, digitalne, hibridne i virtualne knjižnice, a da termini još uvijek nisu definirani do kraja. ${ }^{5}$ Termin virtualna knjižnica najčešće koristimo jer je jasno definiran. Sama riječ virtualan označava ono što je nastalo, odnosno djeluje uz pomoć računala, interneta. ${ }^{6}$

Pri oblikovanju svojih virtualnih knjižnica školski su knjižničari uglavnom slijedili sve važne sastavnice nastavnih mrežnih stranica, a to je da su povezane s kurikulumom; sadrže informacije iz kojih učenici mogu učiti; potiču učenikovo kritičko mišljenje postavljanjem pitanja; sadrže poveznice na tiskane i/ili elektroničke izvore koje učenici mogu koristiti; potiču učenike na korištenje/primjenu informacijskih vještina i uključuju multimedijalne oblike (fotografiju, zvuk i video). Prioritet pri oblikovanju i ponudi sadržaja bio je vjerodostojnost, kvaliteta i profesionalnost, pri čemu se slijede tri kriterija: edukacijski kriterij ili kriterij sadržaja, pouzdanost izvora te tehnička pouzdanost. ${ }^{7}$

\section{Virtualne knjižnice okupljene na jednom mjestu}

Iako koncepti obrazovanja na daljinu u teoriji i praksi postoje desetljećima, situacija u kojoj se krenulo na nastavu na daljinu od 16. ožujka 2020. ukazala je na sve tehnološke i teorijske nedostatke. Dobar je primjer sustav učenja na daljinu Omega koji je nastao kao rezultat procesa evaluacije, testiranja i odabira programskog rješenja za upravljanje $e$-učenjem provedenog u sklopu MZOSova projekta „Organizacija informacija i znanja u elektroničkom obrazovnom okruženju“. 8

Praksa škola, pa i školskih knjižničara, morala je krenuti korak ispred postojeće teorije. U novonastaloj situaciji bilježi se značajan angažman (ponekad je riječ i o samosagorijevanju) svih dionika odgojno-obrazovnoga procesa, od učenika, roditelja, nastavnika, pa do stručnih suradnika. Stručni su suradnici školski knjiž-

Str. 23. [citirano: 2020-10-15]. Dostupno i na: https://www.azoo.hr/app/uploads/uvezeno/datoteke/24-proljetna-skola-knjiznicara2012-web-1536868611.pdf

5 O problemima terminologije i definiranja pojmova više u: Turčin, V.; L. Valčić. Rad u digitalnoj knjižnici. 2002. [citirano: 2020-10-15]. Dostupno na: http://eprints.rclis.org/6142/1/knjiga.pdf.

6 Virtualan. // Hrvatska enciklopedija, mrežno izdanje. Leksikografski zavod Miroslav Krleža, 2021. [citirano: 2020-10-15]. Dostupno na: http://www.enciklopedija.hr/Natuknica.aspx?ID=64792.

7 Herring, E. J. Nav. dj., str. 44-53.

8 Više: Klindžić, J.; M. Banek Zorica; N. Lazić. Sustav učenja na daljinu Omega: prvo desetljeće. // Informacijska tehnologija u obrazovanju / Lasić-Lazić, Jadranka (ur.). Zagreb: Zavod za informacijske studije Odsjeka za informacijske i komunikacijske znanosti Filozofskog fakulteta Sveučilišta, 2014. Str. 59-76. 
ničari, prema uputama Ministarstva znanosti i obrazovanja, Smjernicama Zavoda za knjižničarstvo Nacionalne i sveučilišne knjižnice u Zagrebu i Preporukama Hrvatskog zavoda za javno zdravstvo ${ }^{10}$ krenuli u prikupljanje i oblikovanje poveznica koje će pomoći učiteljima, učenicima i roditeljima u održavanju nastave na daljinu. Smjernice Zavoda su, između ostaloga, preporučile da knjižnice i knjižničari trebaju dati potporu odgojno-obrazovnome procesu u obliku osiguranja građe za učenje i poučavanje dostupne online uz poštivanje autorskih prava; pretraživati izvore i izraditi popise korisnih adresa na kojima se mogu čitati i/ ili preuzimati $e$-knjige; organizirati $e$-seminare za korisnike (učenike, nastavnike, stručne suradnike); rad na većoj vidljivosti knjižnica na mrežnim stranicama škola; stručno usavršavanje knjižničara i preporuka da se knjižničari mogu dodatno angažirati u izradi popisa relevantnih i vjerodostojnih izvora informacija o bolesti COVID-19. Pouzdane informacije i poveznice o COVID-19 za potrebe knjižnica okupila je IFLA na poveznici: https://www.ifla.org/covid-19-and-libraries. IFLA je dala i preporuku da knjižnice pružaju vrijedne zbirke pouzdanih informacija o koronavirusu kako bi ljudima pružile izvor kojem mogu vjerovati. ${ }^{11}$

Osim toga, kao kulturnu i javnu djelatnost, knjižničari mogu organizirati tematske izložbe na mrežnim stranicama škole; online edukativne radionice; čitanje odlomaka knjiga, online pričaonice, edukativne mrežne radionice iz različitih obrazovnih predmeta te prikupiti i organizirati poveznice na izvore ostalih knjižnica s obrazovnim i zabavnim sadržajima namijenjenima djeci. Npr. knjižnica Osnovne škole Dubovac šesnaest godina širi svoj fond, usluge i aktivnosti u virtualni prostor na svojim mrežnim stranicama http://os-dubovac-ka.skole.hr/skola/ knjiznica/. Sadržaji koji se odnose na učenje i poučavanje, informiranje o trenutnim i prošlim knjižničnim aktivnostima, ali i zabavu, dostupni su na tridesetak mrežnih podstranica koje knjižničarka redovito dopunjava i ažurira.

Školski knjižničari najčešće imaju mrežne stranice knjižnica u sklopu službenih mrežnih stranica škola, međutim, sada su te stranice dobile novu dimenziju.

Mnogi su stručni suradnici školski knjižničari, osim tih službenih stranica, izradili nove mrežne stranice virtualnih knjižnica, digitalne repozitorije izvora i baze poveznica. S druge strane, ovo je bila prilika da određeni broj knjižničara prvi put oblikuje svoje mrežne stranice i tako proširi poslovanje

\footnotetext{
9 Smjernice za rad školskih knjižnica u uvjetima bolesti COVID-19. [citirano: 2020-09-14]. Dostupno na: http://maticna.nsk.hr/wp-content/uploads/2020/05/Smjernice-za-rad-s\%CC\%8Ckolskih-knjiz\%CC\%8Cnica-u-uvjetima-bolesti-COVID-19-2020-05-03.pdf.

10 Hrvatski zavod za javno zdravstvo. Preporuke za rad u knjižnicama i antikvarijatima tijekom epidemije koronavirusa (COVID-19). [citirano: 2020-04-24]. Dostupno na: https://www.hzjz.hr/ wp-content/uploads/2020/03/Preporuke-za-rad-u-knjižnicama-i-antikvarijatima-tijekom-epidemije-koronavirusa-COVID-19.pdf.

11 Kosciejew, M. The coronavirus pandemic, libraries and information: a thematic analysis of initial international responses to COVID-19. // Global Knowledge, Memory and Communication 1/2 (2020). DOI: https://doi.org/10.1108/GKMC-04-2020-0041.
} 
u virtualno okruženje. Virtualne knjižnice imaju dodatnu prednost, posebno tijekom učenja na daljinu i može se reći da su svojevrsni alat za dijeljenje koji omogućuje knjižničarima i ostalim nastavnicima povezivanje raznovrsnih resursa.

Hrvatska mreža školskih knjižničara željela je olakšati pristup svim zainteresiranim korisnicima tih izvora, ali i sačuvati radove školskih knjižničara, njihov trud i znanje. Zato se još krajem ožujka 2020. započelo s okupljanjem tih mrežnih stranica na jednome mjestu, odnosno na Repozitoriju školskoga knjižničarstva UDK02, koji postoji još od 2006. godine, kao projekt Hrvatske mreže školskih knjižničara, kojim se željelo omogućiti knjižničarima dijeljenje primjera dobre prakse, kao jedan od najvažnijih i najvrjednijih oblika stručnog usavršavanja školskih knjižničara. Da se okupljanje svih tih stranica na jednome mjestu pokazalo korisnim i dobrim, govori i činjenica kako su poslije školskih to učinile i narodne knjižnice. Na repozitoriju hrvatskoga knjižničarstva UDK02 nalaze se poveznice za 243 virtualne knjižnice. Od toga su 183 knjižnice osnovnih škola, a 60 srednjih škola, a prijave stižu i dalje. Poveznice virtualnih knjižnica nalaze se na Repozitoriju i dostupne su na: bit.ly/VirtualneNa1! Baza je nazvana „Virtualne knjižnice na jednom mjestu“, a knjižnice su na ulaznoj stranici poredane abecedno, što je vidljivo i na slici 1.

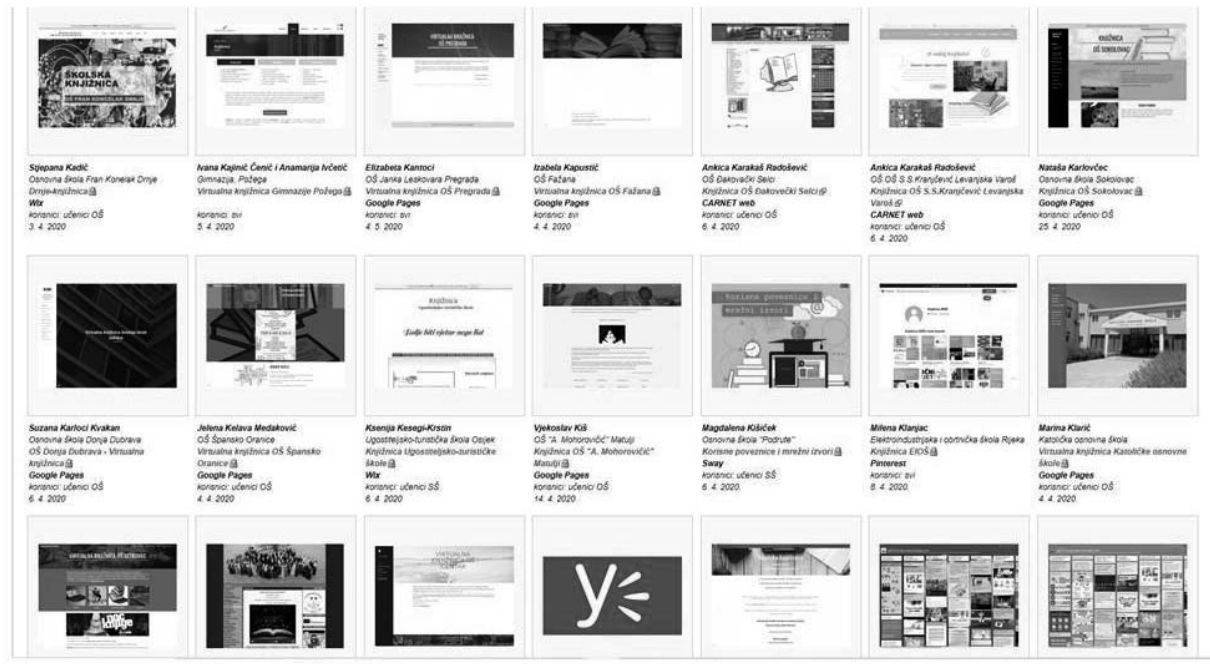

Slika 1. Virtualne knjižnice na jednome mjestu. Baza na repozitoriju školskoga knjižničarstva UDK02 


\section{Taksonomija sadržaja virtualnih knjižnica}

Svaka školska knjižnica ima svoje specifičnosti te je prema njima oblikovala svoju mrežnu stranicu. Što se postavljenih materijala tiče, nema velikih razlika između osnovnoškolskih i srednjoškolskih knjižnica, osim, npr., što knjižnice osnovnih škola imaju upute kako se prijaviti u srednju školu, dok na stranicama knjižnica srednjih škola nalazimo savjete i upute za državnu maturu. Na svim su stranicama postavljeni materijali i poveznice koje možemo svrstati u nekoliko općih kategorija, kao što su: digitalni alati, mediji i medijska pismenost, poticanje čitanja, $e$-knjige i $e$-časopisi, informacije i savjeti, kulturna i javna djelatnost, slobodno vrijeme, podrška nastavnom procesu, projekti.

Na slici 2 može se vidjeti što su sve sadržavale pojedine kategorije te se vidi širina obuhvaćenih tema, ali i da poveznice i materijali nisu namijenjeni samo učenicima i učiteljima, već i njihovim obiteljima, odnosno kako najmlađim tako i najstarijim članovima obitelji.

Analiza sadržaja i tema virtualnih knjižnica pokazuje kako su knjižnice napravile i korak dalje i izišle iz okvira te pružale i emocionalnu potporu svojim zajednicama i korisnicima, tijekom izolacije i stroge fizičke udaljenosti.

Osim što su sadržaji izrađeni u raznim digitalnim alatima, knjižničari su izrađivali ili dijelili upute kako koristiti pojedine alate. Rad na daljinu ponovno je osvijestio pitanja autorskih prava, zaštite podataka na internetu te pravila ponašanja u virtualnom svijetu, a podučiti svoje korisnike svemu tome bila je jedna od glavnih zadaća knjižničara kao informacijskih stručnjaka. Školski knjižničari nisu zaboravili niti svoju primarnu zadaću, a to je poticanje čitanja te se na stranicama može naći mnoštvo snimljenih materijala u kojima knjižničari čitaju priče, pozivaju na aktivnosti vezane za čitanje i savjetuju što čitati. Na virtualnim se stranicama nalaze savjeti i pedagoških i psiholoških stručnjaka o učenju na daljinu, o snalaženju u novonastalim uvjetima te kako korisnici mogu sebi, ali i drugima pomoći u olakšavanju svih negativnih posljedica za psihičko i fizičko zdravlje koje je izazvala bolest COVID-19. Zatvaranje škola i prelazak na online nastavu te rad od kuće donio je to da su obitelji po cijele dane bile zajedno. Jedan dio dana ispunila je nastava, ali nakon toga trebalo je ispuniti slobodno vrijeme, a da to ne bude samo igrajući računalne ili PS-igrice. I ovdje su knjižničari pokazali svoju kreativnost te se na virtualnim stranicama nalaze poveznice na igre, filmove, glazbu, online tečajeve i savjete kako što bolje iskoristiti vrijeme bez škole, ali i vrijeme koje se provodi u krugu obitelji. 


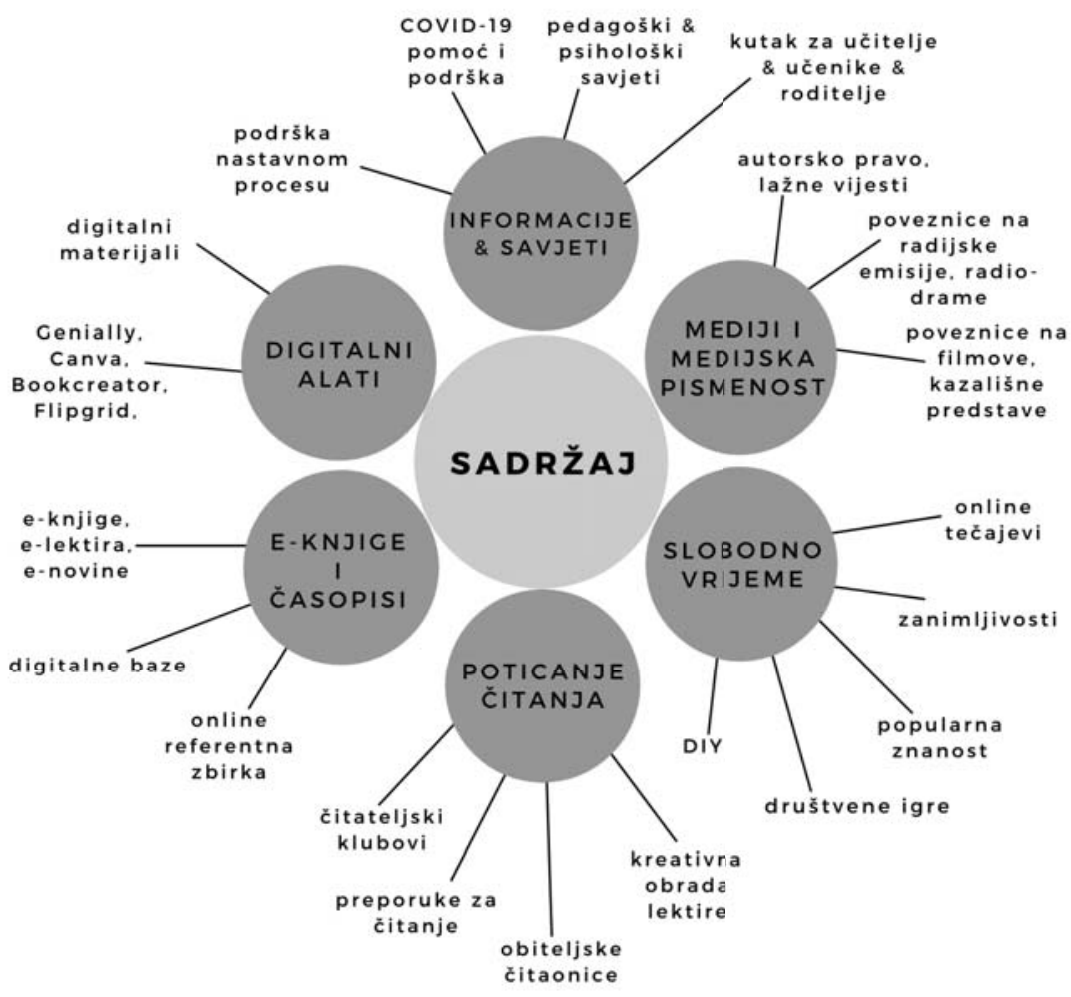

Slika 2. Taksonomija sadržaja opisuje što je predstavljeno u virtualnim knjižnicama

Pri oblikovanju poveznica glavni je cilj bio koristiti otvorene obrazovne sadržaje (engl. Open Educational Resources) ili skraćeno OER obrazovne sadržaje koji su javno dostupni ili objavljeni pod otvorenom licencom. Njihova odlika otvorenosti odnosi se na mogućnosti legalnoga i slobodnoga preuzimanja, upotrebe, prilagodbe i dijeljenja među korisnicima, a neki su od njih: CARNetov repozitorij; portal Toni Milun; Portal za besplatnu pripremu državne mature; portali izdavača (Školska knjiga, Alfa, Profil-Klett i sl.). Neupitno je da knjižnice imaju važnu ulogu u promicanju pristupačnosti i OER-a. U tome se nadovezuju na svoju dugu povijest kao provjerene institucije koje osiguravaju pristup informacijama i nude nastavnicima i učenicima alate potrebne za učinkovito provođenje istraživačkih i nastavnih zadataka. Međutim, istraživanja poput ankete o dostupnosti materijala koja je provedena među nastavnicima sveučilišta Rutgers ${ }^{12}$ ukazuju na

12 Todorinova, L. ; Z. T. Wilkinson. Incentivizing faculty for open educational resources (OER) adoption and open textbook authoring. // Journal of Academic Librarianship 46, 6 (2020), str. 1. DOI:10.1016/j.acalib.2020.102220. 
to da znanje nastavnika i knjižničara o OER-u i njihova voljnost za stvaranjem otvorenog materijala značajno variraju.

Kulturna i javna djelatnost čini veliki dio knjižničarskih aktivnosti. S obzirom na to se da cjelokupna kulturna scena preselila u virtualni svijet, knjižničari su, zahvaljujući virtualnim knjižnicama, svojim korisnicima i široj zajednici približili taj svijet. Slika 3 sadrži vizualni prikaz tema zastupljenih iz područja kulturne i javne djelatnosti. Pregledom mrežnih stranica vidljivo je da su knjižničari na njima dijelili informacije o događanjima u svojoj zajednici i šire, pozivali na gledanje online kazališnih predstava, organizirali virtualne susrete s književnicima, aktivno sudjelovali u događanjima te organizirali izložbe, natječaje i kvizove. Jedan od najzastupljenijih događaja u kojima su sudjelovali knjižničari svakako je Noć knjige u kojoj su, organiziranjem raznovrsnih aktivnosti, željeli privući što veći broj posjetitelja. Jedna od aktivnosti koju knjižničari najčešće provode jest obilježavanje značajnih datuma, a u takva su obilježavanja često aktivno uključivali učenike koji su sudjelovali u kvizovima ili slali svoje literarne, likovne i druge radove. Od tih su radova najčešće oblikovane virtualne izložbe u raznim digitalnim alatima.

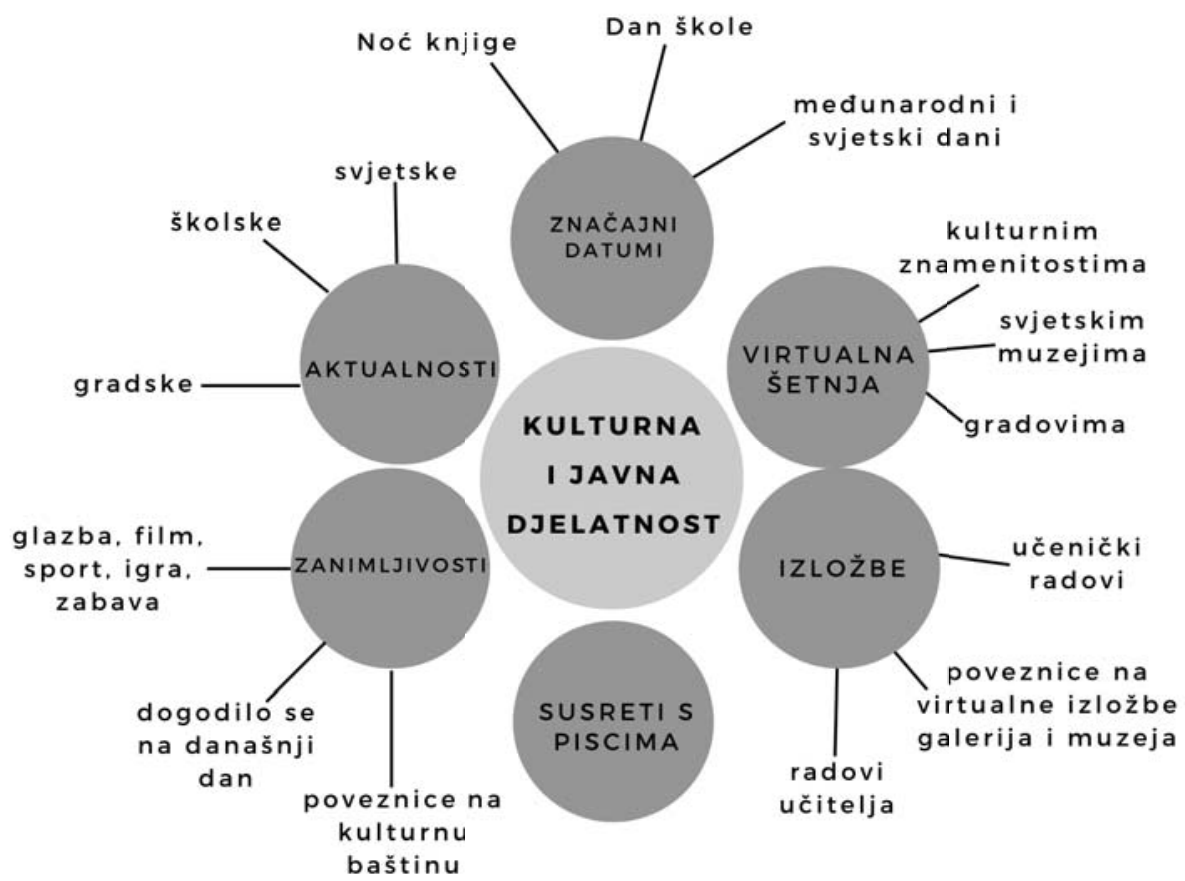

Slika 3. Analiza tema iz područja kulturne i javne djelatnosti 


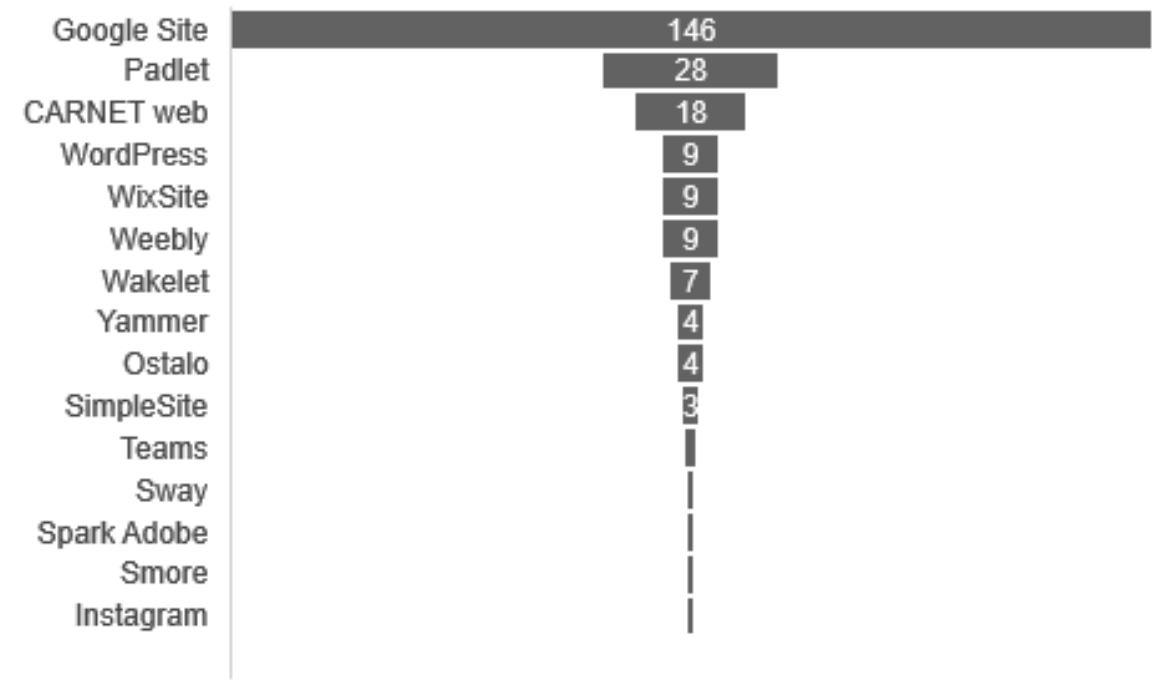

Slika 4. Digitalni alati koje su koristili knjižničari pri izradi virtualnih knjižnica

Kako je vidljivo iz slike 4, pri izradi virtualnih knjižnica knjižničari su uglavnom koristili servis Google Sites koji omogućuje jednostavnu i laku izradu mrežnih stranica, uz prihvatljiv konačan izgled. Tomu je, vjerojatno, pridonio i niz webinara o tome kako napraviti stranicu u navedenom alatu. Osim njega, koristio se, u većoj mjeri, i Padlet, ali i Carnetova platforma, Wakelet, WordPress i Weebly. Webinare je organizirala viša savjetnica za školske knjižničare Adela Granić iz Agencije za odgoj i obrazovanje.

\section{Rasprava}

Vrijeme pandemije ukazalo je kako su školske knjižnice morale pronaći najbolje načine kako „služiti“ svojim školskim zajednicama u virtualnome prostoru ili riskirati potpun gubitak značaja. Ograničenja i nedostaci zbog kojih su knjižničari prije bili „neskloni virtualnim prostorima“ tijekom pandemije postali su nebitni. Školski su se knjižničari našli na prekretnici u kojoj je vrijedio ultimatum - ako nisi prisutan virtualno, ne postojiš. ${ }^{13}$ Nameće se pitanje jesu li virtualne knjižnice oblikovane tijekom pandemije „točka preokreta“ (tipping point),${ }^{14}$ (mali) korak prema trajnim (velikim) promjenama u školskom knjižničarstvu?

13 Brooks Kirkland, A. The virtual library learning commons: leveraging the pandemic tipping point for lasting change. // School Libraries in Canada 4, 2(2020). [citirano: 2020 -11-30]. Dostupno na:.https://journal.canadianschoollibraries.ca/the-virtual-library-learning-commons-leveraging-the-pandemic-tipping-point-for-lasting-change/.

14 Prema Gladwellu, tri su ključne činjenice vezane uz ideje, proizvode, poruke i ponašanje: šire se poput virusa, male promjene mogu imati veliki učinak, a treća, ključna činjenica, jest da se pro- 
U prilog tezi da su virtualne knjižnice napravljene kvalitetno može se izdvojiti nekoliko konkretnih primjera školskih virtualnih knjižnica osnovnih i srednjih škola, poput stranica Knjižnica Osnovne škole Markovac (https://bit.ly/3aWoGnI), III. osnovne škole Čakovec (https://bit.ly/3aWIkjj), Osnovne škole Monte Zaro iz Pule (https://bit.ly/3d8Zwoq), Ekonomske i upravne škole u Splitu (https://bit. ly/3jHglrS) i Srednje škole Braće Radić (https://bit.ly/2Nlaaxo). Na njihovim stranicama uočavaju se sve važne sastavnice i elementi virtualnih knjižnica.

Smjerokaz, polazište i početna točka u radu školskih knjižničara uglavnom su bile stranice Ostajem doma (https://bit.ly/3p9BADX) i Virtualni svijet korisnih informacija (https://bit.ly/2Z6ikwm) na kojima se nalazi mnoštvo poveznica i ideja, što je vidljivo iz početne stranice Virtualnog svijeta korisnih informacija (slika 5).

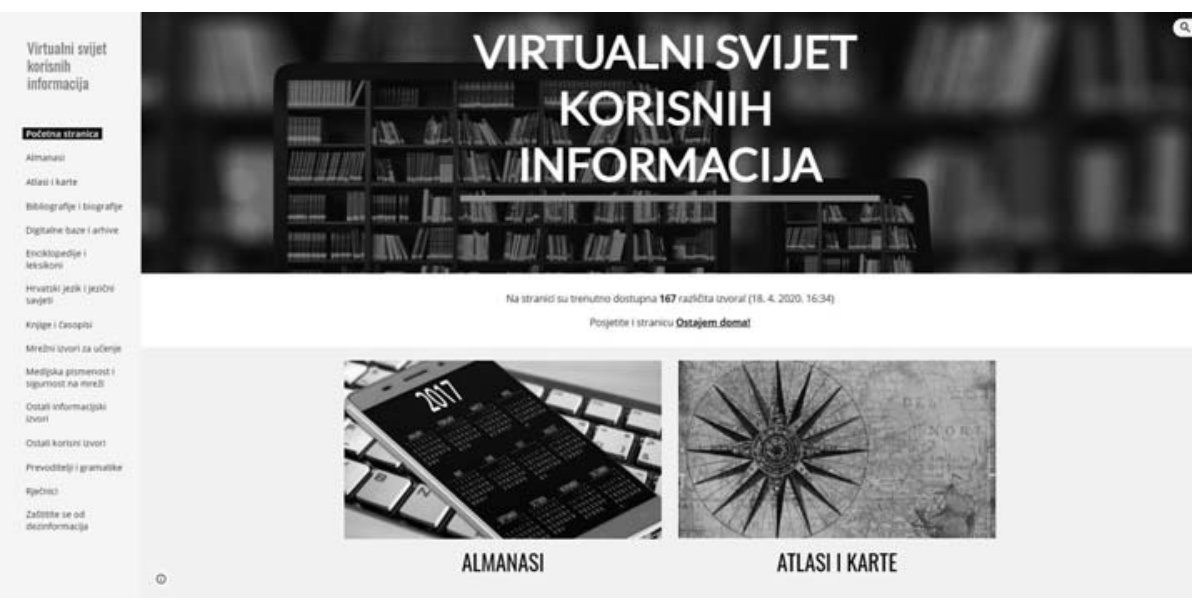

Slika 5. Virtualni svijet korisnih informacija

Dosadašnja iskustva valja promatrati i analizirati i sa stajališta uočenih nedostataka. Naša kratka i nepotpuna analiza može se svesti na nekoliko ključnih teza i može poslužiti kao polazište za daljnju raspravu.

1. U većini virtualnih knjižnica nedostaje komponenta učenja i poučavanja školskoga knjižničara kao što je izrada vlastitih tutorijala i ostalih materijala za učenike i nastavnike. Korak je to koji označava prijelaz od aktivnoga prema proaktivnome školskome knjižničaru.

2. Svi su knjižničari koristili iste poveznice i nedovoljno je prisutna selekcija i vrednovanje poveznica.

3. Nema optimizacije mrežnih stranica za tražilice (SEO - Search Engine Optimisation), odnosno prilagođavanja web-sjedišta internetskim pre-

mjene događaju naglo i dramatično. Više o tipping point $\mathrm{u}$ : Gladwell, M. Točka preokreta: kako male stvari mogu dovesti do velike promjene. Zagreb: Naklada Jesenski i Turk, 2005. 
traživačima, poput Googlea, Binga i drugih. SEO omogućavam knjižnicama da, osim što su prisutne na internetu, budu i vidljive tako što prilagođava internetske stranice kako bi ih pretraživači lakše pronalazili. To je važan korak u stvaranju virtualnih knjižnica kako bi ih korisnici odmah pronašli, ali i kako bi podijelili svoj sadržaj sa što većim brojem ljudi.

4. Malo je virtualnih knjižnica koje omogućuju uključivanje korisnika u oblikovanje svojih sadržaja, a može se reći da se korištenje povećava samo ako svi članovi školske zajednice aktivno sudjeluju u njegovom oblikovanju. ${ }^{15}$ Jedan je to, ali ne i jedini razlog nedovoljnoga korištenja virtualnih knjižnica.

5. Nedostatna je promocija knjižničnih kataloga i bazičnih usluga knjižničara, kao što je usluga Pitaj knjižničara i sl.

6. Malo je sadržaja koji se mogu slobodno koristiti i koji su dostupni u javnoj domeni (budući da nema podataka za Hrvatsku, kao ilustracija može poslužiti podatak koji govori da je u Češkoj samo 19,41 \% javno dostupnih sadržaja). ${ }^{16}$

7. S ograničenjima vezanim uz autorska prava suočavaju se sve virtualne knjižnice koje s jedne strane nastoje omogućiti kopiranja i digitalne reprodukcije dokumenata i olakšati pristup korisnicima, ali s druge strane, upućene su na poštivanje autorskih i srodnih prava. Jedna je od odgovornosti knjižnica edukacija o autorskim pravima, što može biti važan segment virtualnih knjižnica.

8. S obzirom na to da su virtualne knjižnice napravljene zahvaljujući velikom entuzijazmu knjižničara, ali u kratkome vremenu, što je onemogućio opsežnije razmatranje što se i na koji način želi postići, trebalo bi se dodatno poraditi na kvaliteti stranica i njihovoj vidljivosti.

Ovo je bio kratki prikaz pozitivnih i negativnih obilježja virtualnih knjižnica. Alka Stropnik ${ }^{17}$ u svome Prijedlogu Smjernica za knjižnične mrežne stranice za mlade već je dala osnovne smjernice kojima bi se trebali voditi knjižničari pri stvaranju svojih mrežnih stranica, a jesu li se knjižničari svega toga i držali, otkrila bi detaljnija analiza postojećih virtualnih knjižnica.

15 Dukić, Z. Nav. dj., str. 31.

16 Pokorná, L.; M. Indrák; M. Grman; F. Stepanovsky; M. Smetánková. Silver lining of the COVID-19 crisis for digital libraries in terms of remote access. // Digital Library Perspectives 36, 4 (2020), str. 400. DOI: https://doi.org/10.1108/DLP-05-2020-0026.

17 Stropnik, A. Knjižnica za nove generacije: virtualni sadržaji i usluge za mlade. Zagreb: Hrvatsko knjižničarsko društvo, 2013. Str. 51-75. 


\section{Zaključak}

Školske knjižnice moraju kvalitetno odgovoriti na sve veće izazove u dinamičnom društvenom i obrazovnom okruženju te velik dio svojih aktivnosti i usluga preseliti u online okruženje. Zbirke školskih knjižnica također se mijenjaju i sve se više naglašava sakupljanje i vrednovanje izvora informacija u digitalnome obliku i oblikovanju virtualnih knjižnica. Školski knjižničari redovito moraju ažurirati i proširivati svoja znanja, prije svega, u području informacijskih vještina i informacijske pismenosti.

Kroz oblikovanje virtualnih knjižnica, školski su knjižničari još jednom potvrdili svoju osviještenost i svoju stručnost. U vrlo kratkom vremenu uspjeli su biti odlična podrška nastavnome procesu, desna ruka u nastavi na daljinu svim učiteljima i učenicima, a nisu zaboravili ni ostale poslove školskih knjižničara, kao što je, na primjer, kulturna i javna djelatnost. Pred knjižničarima je i dalje veliki posao, jer sve te stranice treba neprestano dopunjavati i ažurirati. Puno je poveznica koje više nisu dostupne, a svakim se danom pojavljuje i mnogo drugih materijala koje treba pronaći, usustaviti i podijeliti s korisnicima. Osim toga, potrebno je stvarati i vlastite digitalne materijale te uključiti korisnike u stvaranje stranica.

Postoji zamisao i o jednoj zajedničkoj stranici s koje bi knjižničari mogli povlačiti poveznice i materijale i prilagođavati ih svojim mrežnim stranicama i svojim potrebama, ali u nedostatku vremena i knjižničara koji bi se time bavili, za sada to ostaje samo zamisao. Imaju li naše katedre za knjižničarstvo interesa i mogućnosti za realizaciju takve ideje? Udruga Hrvatska mreža školskih knjižničara učinila je prvi korak i okupila poveznice na jedno mjesto, oblikovala bazu koja se proširuje iz dana u dan, a za održavanje i kvalitetu virtualnih knjižničnih stranica trebat će još dosta rada i stručne podrške.

\section{LITERATURA}

Banek Zorica, M. E-učenje temeljeno na objektima učenja. // Informacijska tehnologija u obrazovanju / Lasić-Lazić, J. (ur.). Zagreb: Zavod za informacijske studije Odsjeka za informacijske i komunikacijske znanosti Filozofskog fakulteta Sveučilišta, 2014. Str. 33-59.

Brooks Kirkland, A. The virtual library learning commons: leveraging the pandemic tipping point for lasting change. // School Libraries in Canada 4, 2 (2020). [citirano: 2020 -11-30]. Dostupno na:.https://journal.canadianschoollibraries.ca/the-virtual-library-learning-commons-leveraging-the-pandemic-tipping-point-for-lasting-change/. 
Dukić, Z. Školske knjižnice u virtualnom prostoru: od mrežne stranice do virtualne zajednice učenja. // XXIV. Proljetna škola školskih knjižničara Republike Hrvatske. Smjernice za rad školskog knjižničara / Mićanović, Miroslav (ur.). Zagreb: Agencija za odgoj i obrazovanje, 2012. Str. 23-32. [citirano: 2020-10-15]. Dostupno i na: https://www.azoo.hr/app/uploads/uvezeno/datoteke/24-proljetna-skola-knjiznicara2012-web-1536868611.pdf.

Gladwell, M. Točka preokreta: kako male stvari mogu dovesti do velike promjene. Zagreb: Naklada Jesenski i Turk, 2005.

Herring, E. J. Internetske i informacijske vještine: priručnik za učitelje i školske knjižničare. Zagreb: Naklada Nediljko Dominović, 2008.

Hrvatski zavod za javno zdravstvo. Preporuke za rad u knjižnicama i antikvarijatima tijekom epidemije koronavirusa (COVID-19). [citirano: 2020-04-24]. Dostupno na: https://www.hzjz.hr/wp-content/uploads/2020/03/Preporuke-za-rad-u-knjižnicama-i-antikvarijatima-tijekom-epidemije-koronavirusa-COVID-19.pdf.

Klindžić, J.; M. Banek Zorica; N. Lazić. Sustav učenja na daljinu Omega: prvo desetljeće. // Informacijska tehnologija u obrazovanju / Lasić-Lazić, J. (ur.). Zagreb: Zavod za informacijske studije Odsjeka za informacijske i komunikacijske znanosti Filozofskog fakulteta Sveučilišta, 2014. Str. 59-76.

Kosciejew, M. The coronavirus pandemic, libraries and information: a thematic analysis of initial international responses to COVID-19. // Global Knowledge, Memory and Communication, 1/2 (2020). DOI: https://doi.org/10.1108/GKMC-04-2020-0041.

Pokorná, L.; M. Indrák; M. Grman; F. Stepanovsky; M. Smetánková. Silver lining of the COVID-19 crisis for digital libraries in terms of remote access. // Digital Library Perspectives 36, 4 (2020), 389-401. DOI: https://doi.org/10.1108/DLP-05-20200026.

Preporuka Europskog parlamenta i savjeta; ključne kompetencije za cjeloživotno učenje - Europski referentni okvir. // Metodika 11, 20 (2010), 169-182. [citirano: 2020-1008]. Dostupno na: https://hrcak.srce.hr/61536.

Smjernice za rad školskih knjižnica u uvjetima bolesti COVID-19. [citirano: 202009-14]. Dostupno na: http://maticna.nsk.hr/wp-content/uploads/2020/05/Smjernice-za-rad-s\%CC\%8Ckolskih-knjiz\%CC\%8Cnica-u-uvjetima-bolesti-COVID-19-2020-05-03.pdf.

Stropnik, A. Knjižnica za nove generacije: virtualni sadržaji i usluge za mlade. Zagreb: Hrvatsko knjižničarsko društvo, 2013.

Todorinova, L.; Z. T. Wilkinson. Incentivizing faculty for open educational resources (OER) adoption and open textbook authoring. // Journal of Academic Librarianship 46, 6(2020), 1-10. DOI:10.1016/j.acalib.2020.102220

Turčin, V.; L. Valčić. Rad u digitalnoj knjižnici. 2002. [citirano: 2020-10-15] Dostupno na: .http://eprints.rclis.org/6142/1/knjiga.pdf.

Virtualan. // Hrvatska enciklopedija, mrežno izdanje. Leksikografski zavod Miroslav Krleža, 2021. [citirano: 2020-10-15]. Dostupno na: http://www.enciklopedija.hr/Natuknica.aspx?ID=64792. 